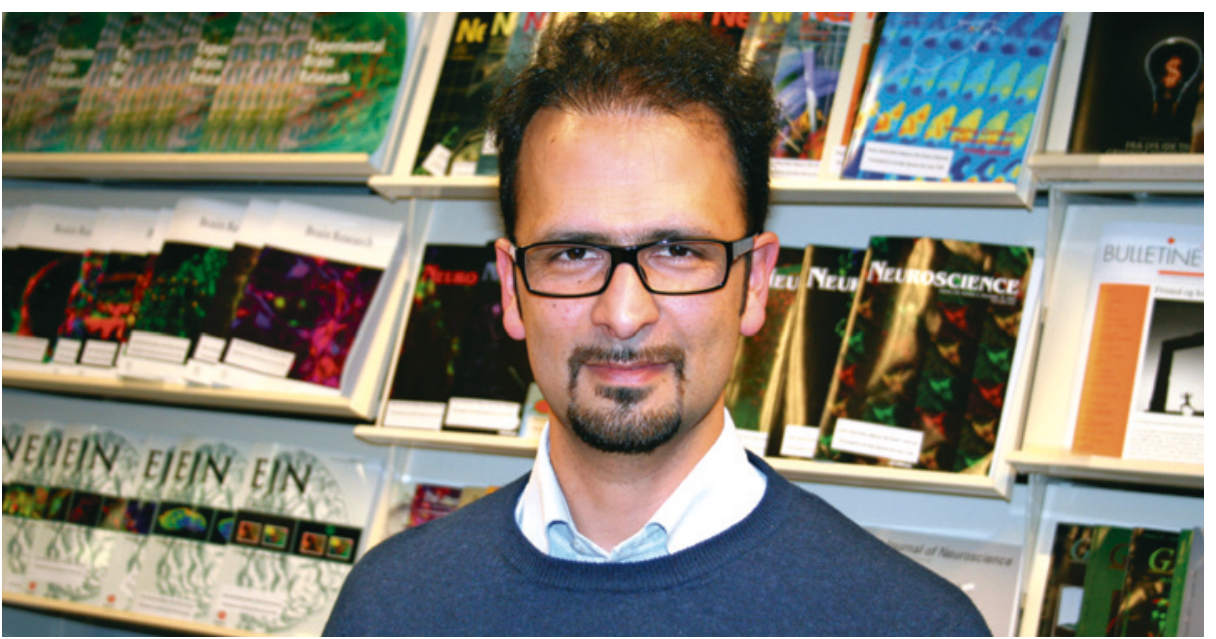

Mahmood Amiry-Moghaddam. Foto Marit Tveito
Ordforklaringer

Cerebral malaria: En alvorlig manifestasjon av malaria hvor hjernen rammes. Dødeligheten er spesielt høy hos barn. Skyldes infeksjon med malariaparasitten Plasmodium falciparum.

Vannkanaler: Membranproteiner som danner porer i cellemembranen og som er mer eller mindre selektivt permeable for vann. Det finnes 13 ulike typer av vannkanaler hos pattedyr, og disse uttrykkes i de fleste organer i kroppen. Akvaporin 4 (AQP4) er vannkanalen som det uttrykkes mest av i hjernen. Den spiller en viktig rolle i danning av hjerneødem.

Hjerneødem: Ansamling av vann i og utenfor hjerneceller. Hjerneødem er en alvorlig komplikasjon og en viktig årsak til død ved flere akutte nevrologiske sykdommer. Per i dag finnes det ingen behandling for å forhindre utviklingen av hjerneødem.

\title{
Vannkanaler beskytter mot cerebral malaria
}

\author{
Vannkanaler kan være et mulig utgangspunkt for nye behandlings- \\ metoder for å hindre malariainfeksjon i hjernen.
}

Cerebral malaria er en alvorlig og potensielt dødelig nevrologisk manifestasjon ved infeksjon med malariaparasitten Plasmodium falciparum. Malaria er utbredt i tropiske og subtropiske strøk. Det er særlig barn under ti år som rammes av cerebral malaria.

Forskere ved Universitetet i Oslo har i samarbeid med amerikanske forskere vist at hjernens vannkanaler beskytter mot cerebral malaria (1). I en musestudie hadde malariainfiserte mus færre akvaporin 4-kanaler (AQP4) i hjernen enn ikke-infiserte mus. Genmodifiserte mus som manglet AQP4 og som ble infisert med malaria, ble raskere syke og utviklet mer alvorlig hjerneødem enn vanlige mus. De genmodifiserte musene hadde også dårligere effekt av malariabehandling - kun $20 \%$ overlevde, mot $80 \%$ av vanlige mus. Funnene tyder på akvaporin 4 gir en delvis beskyttelse mot cerebral malaria.

- Vannkanalene gir større sjanse for å overleve cerebral malaria og sannsynligvis også andre infeksjonssykdommer i hjernen, sier professor i anatomi Mahmood AmiryMoghaddam ved Universitetet i Oslo, en av artikkelforfatterne.

- Denne kunnskapen kan på sikt føre til utvikling av nye behandlingsmetoder, for eksempel stimulering av vannkanaleffekten. Foreløpig finnes det ikke behandling som kan blokkere eller aktivere disse vannkanalene. Vi har flere pågående prosjekter om regulering av akvaporin 4 i hjernen - første steg er å vise at den faktisk kan reguleres. Deretter vil vi se på hvordan vi kan utvikle nye behandlingsformer, sier Amiry-Moghaddam.
Akvaporin 4 er den hyppigst forekommende vannkanalen i hjernen, og hittil har den vært kjent for å ha en skadelig heller enn nyttig funksjon. Vannkanalene har vist seg å være viktige for regulering av cellevolumet. - Denne studien er den første som påviser en direkte sammenheng mellom det å ha vannkanaler og økt sjanse for å overleve en sykdom, sier Amiry-Moghaddam.

\section{Forskergruppen}

Studien er et samarbeid mellom Johns Hopkins Malaria Research Institute (JHMRI) ved Johns Hopkins Bloomberg School of Public Health (USA) og Laboratory of molecular neuroscience (LMN) ved Institutt for medisinske basalfag, Universitetet i Oslo. Professor Peter Agre, artikkelens sisteforfatter, fikk nobelprisen i kjemi i 2003 for oppdagelsen av vannkanalene. Han er direktør for Johns Hopkins Bloomberg School of Public Health, der artikkelens førsteforfatter, Dominique Promeneur, er postdoktor. Fra Universitetet i Oslo bidrar professor Mahmood Amiry-Moghaddam, leder for Laboratory of molecular neuroscience, og ph.d.-stipendiat Lisa Kristine Lunde.

\section{Hanne Støre Valeur}

hanne.store.valeur@legeforeningen.no Tidsskriftet

\section{Litteratur}

1. Promeneur D, Lunde LK, Amiry-Moghaddam M et al. Protective role of brain water channel AQP4 in murine cerebral malaria. Proc Natl Acad Sci U S A 2013; 110: 1035-40.

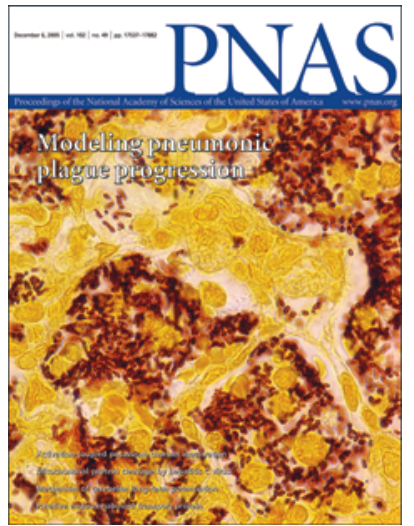

Artikkelen ble publisert i januar 2013 i det prestisjetunge amerikanske tidsskriftet Proceedings of the NationalAcademy of Sciences of the United States of America (www.pnas.org). (C) National Academy of Sciences, USA, 2008 